\title{
Parental Instructional Strategies During Family Visit to An Agricultural Exhibition at A Science Museum
}

\author{
Neta Shaby ${ }^{1 *}$ (]), Orit Ben-Zvi Assaraf ${ }^{2}$ (), Noy Levy ${ }^{2}$ (1)
}

${ }^{1}$ Southampton Education School, University of Southampton, UK
${ }^{2}$ Program of Science and Technology Education, Ben-Gurion University of the Negev, ISRAEL
${ }^{*}$ Corresponding Author: N.Shaby@soton.ac.uk

Citation: Shaby, N., Ben-Zvi Assaraf, O., \& Levy, N. (2022). Parental Instructional Strategies During Family Visit to An Agricultural Exhibition at A Science Museum. Interdisciplinary Journal of Environmental and Science Education, 18(2), e2268. https://doi.org/10.21601/ijese/11663

ARTICLE INFO

Received: 6 Nov. 2021

Accepted: 17 Jan. 2022

\begin{abstract}
The aim of this qualitative study was to examine how parents use exhibits' features during a family visit to a science museum. We observed 44 families during 9 hours and 45 minutes at the "Fields of Tomorrow" exhibition hall. The analysis showed that parents used the physical environment as a resource to engage children with science, taking on the role of "experts" and instructing the novice children. The analysis revealed that parents mainly used four instructional strategies while engaging with the exhibits: 1) connection to everyday life; 2) observation; 3) asking questions; and 4) reading, interpreting, and naming. We also found that parents took advantage of the signs near the exhibits to facilitate their instruction, and their scientific interpretations rarely related to the exhibit's goals. This study highlights the need for better mediational means at science museums to support visitor engagement.
\end{abstract}

Keywords: science museum, parental instructional strategies, interaction analysis

\section{INTRODUCTION}

Accumulating evidence suggests that much of what people learn and know about the world (including the world of science) derives from experiences not only at schools but in a variety of contexts across their lifetime, such as their homes, the outdoors, and museums (Zimmerman et al., 2010). Family engagement with science facilitates children's disciplinary talk, supports their scientific thinking, and scaffolds their understanding of science (Crowley et al., 2001). Family science participation can form the basis for scientific thinking and practice (Ash, 2003, 2004; Crowley \& Jacobs, 2002) and can offer resources to employ during future scientific activities (Callanan \& Jipson, 2001). Science centers provide opportunities for families to engage with science through hands-on activities, interactive exhibits, and direct experience with scientific phenomena (Zimmerman et al., 2010). Museums are places where families play, talk, and learn from each other (Ash, 2003). Families adapt strategies for family learning that have been practiced for many years and are accustomed to learning together. Families visiting science museums equipped with their own ways of communion, an established value, and shared recollections of past events (Ellenbogen et al., 2004; Zimmerman \& McClain, 2016).

There is vast body of knowledge examining parent-child interactions in museums (Andre et al., 2017; Callanan et al.,
2020; Degotardi et al., 2019; Harris \& Winterbottom, 2018; McClain \& Zimmerman, 2019; Taggart et al., 2020; Vandermaas-Peeler et al., 2016) and due to the fact that parents are among the most influential factors in children's learning, there is always the need to add to this body of knowledge. Informal science environments and exhibit designers who wish to promote science learning for children must carefully consider the role of parents in this learning process. This study will add to that vast body of knowledge and will inform the way parents use resources in the museum settings while interacting with exhibits, using various instructional strategies in the specific context of agricultural exhibition.

\section{Family Learning in Science Museums}

Opportunities to engage in science practices and content in everyday family life is abundant and plays a significant role in children's development of science knowledge and skills, and interest (Zimmerman et al., 2010), and identity (Bricker \& Bell, 2014). Thus, family science engagement can establish a basis for scientific thinking and practice (Ash, 2003, 2004; Crowley \& Jacobs, 2002) and can provide resources to draw on during future scientific activity (Callanan \& Jipson, 2001).

As mentioned, museums are places where families play, talk, and learn from each other (Ash, 2003, 2004; Palmquist \& Crowley, 2007; Zimmerman et al., 2010). Parents (or caregivers) are among the most prominent agents in young 
children's learning and development (NRC, 2000). Through engagement in everyday settings and designed environments, children regularly learn about and engage with science (Callanan et al., 2007; Fender \& Crowley, 2007). Parents support science learning directly, by scaffolding learning and modeling, and by supporting interest during science-related interactions (Fender \& Crowley, 2007), and indirectly, by enabling science learning experiences and providing various resources (NRC, 2009). When exhibits design features include various access points, can accommodate multiple users, with multiple possible outcomes and contain content that is relevant to the visitors' prior knowledge and experiences, families are more likely to collaborate while engaging with exhibits and have related conversations about the scientific content (Harris \& Winterbottom, 2018). When a social groupsuch as a family-participate in a collaborative activity, that activity is informed by the individuals engaging with it, but it also reciprocally informs the individuals and the group (Harris \& Winterbottom, 2018). Following this approach, learning takes place in a 'community of practice', which can include any group, including a family, that shares practices, related understandings, assumptions, goals and values, and ways of talking within and about them (Vedder-Weiss, 2017). When interacting with an exhibit, parents frequently direct their children's attention in subtle ways (Crowley et al., 2001; Jant et al., 2014). One way in which parents do this is through the personal connections that they make for the childrenbridging the activities in the museum to shared family stories and to the children's prior experiences and/or knowledge (McClain \& Zimmerman, 2014; Zimmerman et al., 2010).

Families adapt strategies for family learning that have been practiced for many years and are accustomed to learning together. Some studies have, therefore, focused on the way family dynamics play out during the visit, for example, where parents can be a "bridge" or "barrier" to the child's engagement with the content of the exhibit (Willard et al., 2019). Zimmerman et al. (2010) found three social practices that parents employed to facilitate interest during a visit to a science center:

1. Support existing interests through gesture and conversations to the exhibits;

2. Make observations and read museum signage or encourage youth to read and observe; and

3. Evoke and support familiar social practices in the museum.

This study also found that cultural tools (e.g., scientific equipment) and technology (e.g., mobile technologies) promote family interactions and conversations.

Riedinger and Taylor (2019) suggested that parents encourage children's scientific thinking by prompting explanations, modeling how to use evidence and demonstrate how to compare between types of evidence. Other researchers have also observed parents modeling and using inquiry skills to facilitate conversations with their children in science museums (Andre et al., 2017; Degotardi et al., 2019). For instance, Crowley et al. (2001) show that in a study of 91 families (children aged 4 to 8 years old) interacting with a zoetrope in a children's museum, parents facilitated their children's scientific thinking by advising their selection of relevant evidence, thus helping them to create evidence and offer explanations.

Many researchers have shown that parents take on the role of a teacher when visiting various "designed informal learning environments" such as museums, botanical gardens, aquariums, and zoos (Ash, 2003, 2004; Crowley et al., 2001; Ellenbogen et al., 2004; Zimmerman et al., 2010). In their study at a science museum, Szechter and Carey (2009) show that parents commonly engaged in "learning talk" (i.e., describing evidence, giving direction, providing explanations, connecting to past experiences, and making predictions) more often than the children, while children initiate interactions with exhibits and manipulated exhibit components more than parents. Parents often use 'learning-talk' as a strategy to promote engagement when children notice something. They ask questions to draw a child's attention to scientific content and processes and to elicit what the child already understands (Ash, 2004), parents also read explanatory text out-loud to prolong engagement (Diamond, 1986), they ask informationseeking questions, followed by rhetorical or didactic questions (Taggart et al., 2020). Thus, this research aims to shed light on the form of instructional strategies used by parents while interacting with exhibits during a free-choice family visit to an agricultural exhibition at a science museum.

\section{THE EXHIBITION HALL-"FIELDS OF TOMORROW"}

This research was conducted at the Bloomfield Science Museum in Jerusalem, which is an interactive science museum with versatile exhibitions. The study focused on the "Fields of Tomorrow" exhibition, which presents the scientific background to the issue of global and regional sustainability in agriculture, focusing on research and innovations that have been developed in Israel and abroad for sustainability solutions.

Figure 1 presents the layout of the exhibition and its goals, as they appear on the museum website.

\section{Participants}

The science museum in Jerusalem serves the population of the city-Jews and Arabs; religious and secular; and various groups of visitors, such as school students on field trips, families, and tourists. This study was conducted by Hebrew speaking researchers and data was collected on Saturdays, since most family groups visit the museum on this day. Participants included 44 Hebrew speaking families. We chose to observe families who were visiting the exhibition for the first time, to ensure that all interactions were spontaneous and not a product of prior knowledge of the exhibition. For the purpose of this study, a family unit consists of at least one parent and at least one child.

As demonstrated in Table 1, the 44 families included 30 adult men (fathers and grandfathers), 39 adult women (mothers and grandmothers), 42 boys, and 33 girls. Age distribution is given in Table 1. Eight of 30 adult men and four of 39 adult women declared that their occupation was science related. 


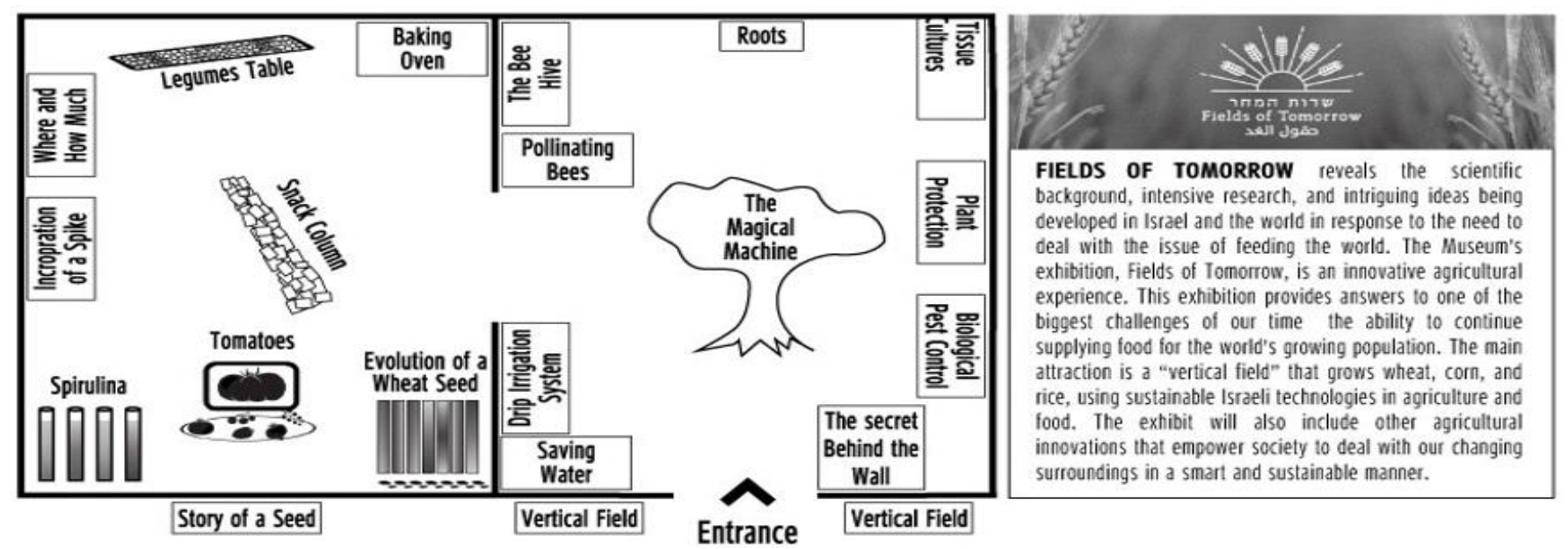

Figure 1. Exhibition layout and specified goals

Table 1. Participants of the study

\begin{tabular}{lclc}
\hline Participants & $\#$ & Age distribution of kids & $\#$ \\
\hline Adult men & 30 & $2-6$ years old & 42 \\
\hline Adult women & 39 & $7-10$ years old & 27 \\
\hline Boys & 42 & $11-14$ years old & 6 \\
\hline Girls & 33 & & \\
\hline Total & $\mathbf{1 4 4}$ & & $\mathbf{7 5}$ \\
\hline
\end{tabular}

\section{Data Collection}

This study used observation as the main tool for data collection. Three researchers collected the data on Saturdays, over the course of six months. Observations included audio recordings of participant speech (which was transcribed later) and field notes of physical activities such as operation of exhibits and gestures (specifically, pointing). Two researchers were present at all times during the observations. One researcher (the third author) was present during all observations, while the other two researchers (first and second authors) alternated.

One researcher approached one or both parents of Hebrewspeaking families at the entrance of the exhibition hall, next to the Vertical Wall asking,

\section{"Have you visited this exhibition before?"}

Only families who were there for the first time were invited to participate in the study. Then, the study was explained to them. The participants were told that this study examines family-interactions during their visit inside the exhibition hall, while being followed around by a researcher audio recording their visit. Participants were ensured about their anonymity. After explaining the goal and data collection tool, participants were asked to give verbal consent to participate. Collecting the data started once we received the parents' permission to follow them and document their conversations and actions, and ended when the family left the exhibition hall. Overall, we observed 44 families during 09:44 hours, with an average of 13 minutes per family.

\section{Data Analysis}

In this analysis we utilized an iterative process of grounded theory thematic analysis (Corbin \& Strauss, 2008) in an inductive, ground-up process to characterize how families facilitated the use of resources during interactions with museum exhibits. This analysis was done in four stages by two researchers (first and second authors). During the first stage, the transcripts (including audio and field notes) were read in their entirety by the two researchers, to write down general impressions and memos. This initial analysis revealed that five of the exhibits, all located in the second area of the exhibition hall (see Figure 1), attracted more visitors. Therefore, in the second stage, we have performed data reduction and focused our in-depth analysis on those five specific exhibits (Figure 2). Data reduction allowed us to reveal the commonalities between those five exhibits, that were clearly more attractive to visitors.

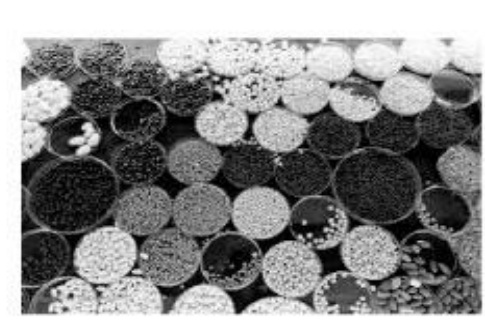

Legumes Table

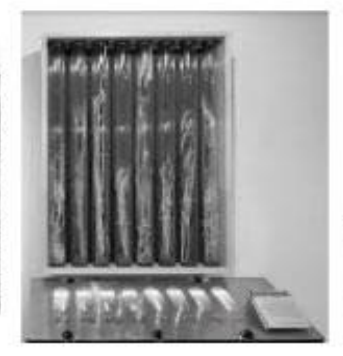

Wheat Exhibit

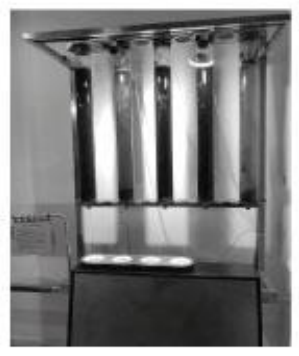

Spirulina
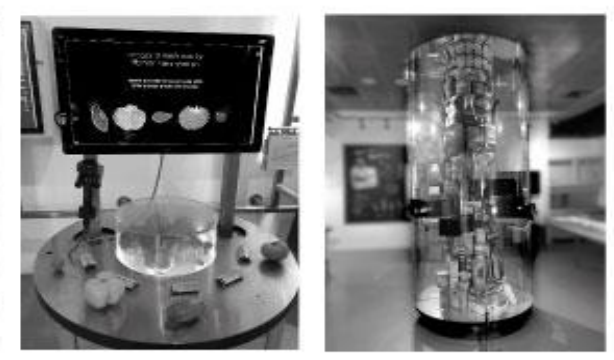

Tomatoes Exhibit Snack column

Figure 2. The five exhibits in the study 
Table 2. Descriptions of the five exhibits in the study

\begin{tabular}{|c|c|}
\hline & \\
\hline umes & $\begin{array}{l}\text { The legume family } \\
\text { The legume family (Fabaceae) includes important food plants such as soy, } \\
\text { This family also contains important fodder plants such as clover and alfalfa } \\
\text { roots have symbiotic relationship with nitrogen-fixing bacteria in the soil } \\
\text { The bacteria cause the roots to develop small bulbs that look like growths } \\
\text { important ecological role by enriching the soil with nitrogen. The pro } \\
\text { complement those found in cereal grains. Together they provide th }\end{array}$ \\
\hline & $\begin{array}{l}\text { This exhibit does not have a phy } \\
\text { "In order to cultivate a certain tomatc } \\
\text { to re } \\
\text { When scanning the barcode, inform } \\
\text { parents, additional }\end{array}$ \\
\hline & $\begin{array}{c}\text { can be eaten only after they have been proce } \\
\text { Throughout the ages humanity has deve }\end{array}$ \\
\hline $\begin{array}{l}\text { Evolution of } \\
\text { a Wheat Seed } \\
\text { *Will be } \\
\text { referred as } \\
\text { Wheat } \\
\text { Exhibit }\end{array}$ & $\begin{array}{l}\text { Improving wheat varieties } \\
\text { How will the stalk withstand the winter winds? Combine the 'stems' with the 'ears' to get a grain-bearing } p \\
\text { the wind. } \\
\text { The ear of wheat is the inflorescence of the wheat plant. The ear grows atop a long stem that reaches } \\
\text { Mankind developed varieties of wheat that contains many large kernels of grain, making the ear so he } \\
\text { bend in strong winds and even break. This phenomenon is called Lodging. The lodging of stalks make } \\
\text { when the stalks touch the ground it causes the transfer of various diseases. In the } 1960 \text { 's scientists cu } \\
\text { wheat that had shorter and thicker stems. This led to a significant increase in worldwide crop yielc }\end{array}$ \\
\hline
\end{tabular}

\section{Food of the future}

Would you eat this green stuff??? The pipes before you contain water with Spirulina - blue-green algae (Cyanobacteria). As the amount of Spirulina in the container increases, the green color of the water becomes darker. Brownish water indicates that the

Spirulina Spirulina has decomposed and is no longer reproducing.

Spirulina contains a large amount of full protein that has all the amino acids essential to the human body. It is defined as a

Super Food - a term that refers to the amount and type of protein, fatty acids, vitamins and minerals found in the food.

The UN food committee declared that Spirulina is the food of the future and NASA proposed using it as food on long-term space missions.

Table 2 provides the signage text that accompanied each exhibit in the museum. The exhibition layout is given in Figure 1, with relevant exhibits illustrated in detail, while the others are marked with a rectangle. In the third stage of analysis, we explored family interactions with the exhibits. During our inductive analysis, it appeared that parents' main interactions with exhibits were instructing their children about the exhibits, using various resources to do so. Therefore, through an iterative process we focused on parental strategies while analyzing family-interactions. In the fourth and last stage, we grouped together those instructional strategies and named them as our main categories.

Throughout the analysis, we attended to the four criteria of trustworthiness (Lincoln \& Guba, 1985). To ensure the credibility and dependability two researchers created detailed descriptions of the transcriptions and field-notes. We addressed the confirmability by iterative analysis in which the analysis was done by the first author and reviewed by the second author. The first author wrote descriptions and examples for each category and sub-categories, those were reviewed by the second author for peer review to confirm whether the examples match the subcategories' descriptions and explanations. All disagreements were discussed until we achieved agreement among the researchers. To ensure transferability we provided "thick descriptions" of the research context to allow other museum researchers to assess whether data were transferable to their context (Lincoln \& Guba, 1985).

\section{RESULTS AND DISCUSSION}

Our first finding from the initial stage of analysis was that five specific exhibits located in the second area of the exhibition hall (see Figure 2) attracted all visitors. We counted the times the families approached all 20 exhibits in the hall. Overall, the 44 families approached various exhibits in the hall 219 times. We counted exhibits more than once if a family approached them more than one time. The five exhibits were approached 167 times altogether (76.3\%), while the other 15 were approached 52 times altogether (23.7\%). Therefore, we focused our in-depth analysis on those particular five exhibits.

Given the nature of our grounded theory-inductive analysis, parental instructional strategies emerged as key characteristic during family interactions with exhibits. Our analysis revealed four major parental instructional strategies 
Table 3. Parental instructional strategies

\begin{tabular}{|c|c|c|c|}
\hline \multicolumn{2}{|l|}{ Parental instructional strategies } & Percentage of families & Number of interactions \\
\hline \multicolumn{2}{|l|}{ Connection to everyday life } & $45 \%$ & 84 \\
\hline \multicolumn{2}{|l|}{ Observation } & $75 \%$ & 80 \\
\hline \multicolumn{2}{|l|}{ Asking questions } & $73 \%$ & 68 \\
\hline \multirow{4}{*}{ Reading, interpreting, and naming } & Read the sign or the instructions & $84 \%$ & 120 \\
\hline & Technical interpretation & $86 \%$ & 98 \\
\hline & Scientific interpretation & $48 \%$ & 37 \\
\hline & Naming & $60 \%$ & 87 \\
\hline
\end{tabular}

Table 4. Examples of parents' references to connections to everyday life

\begin{tabular}{cccc}
\hline $\begin{array}{c}\text { Family } \\
\#\end{array}$ & Family members & Exhibit & Example \\
\hline 9 & Mom, Dad, \& Nofar (6) & Legumes Table & $\begin{array}{c}\text { Mom: Do you remember what you did with this in kindergarten? } \\
\text { Nofar shakes her head no. }\end{array}$ \\
& Mom: You put it on damp cotton wool and made it sprout.
\end{tabular}

during free-choice family exploration of the Fields of Tomorrow exhibition hall:

1. connection to everyday life;

2. observation;

3. asking questions; and

4. reading, interpreting, and naming.

Table 3 demonstrates the distribution of these instructional strategies, which will be explained in the forthcoming sections. Regarding the instructional strategies adopted, we found no notable differences between parents in a science-related occupation and parents in a non-sciencerelated occupation.

\section{Connection to Everyday Life}

Interestingly, in the current study, most families approached the food related exhibits. The findings show that family interactions were characterized by connecting to previous experiences related to their lives. Connection to everyday life was used as an instructional strategy by $45 \%$ of the families, 84 times. To illustrate, one mother tried to engage her daughter with the exhibit by saying,

\section{"This is something you really like,"}

trying to catch the child's attention by creating interest or curiosity, to which the daughter responded positively by approaching and engaging with the exhibit. While engaging with the exhibits, families shared memories, facts, and acquaintance with types of food, in a unique and personal way (see Table 4).

Overall, we found that the Wheat exhibit prompted the most references to a connection to everyday life, especially with younger children (under 6 years old). For example, parents often reminded children that flour is produced from wheat and that bread is made from flour, a process that some of the children were familiar with from pre-school. The parents reminded the children about the Challah bread (traditional Jewish bread) they eat (or ate) every Friday during the Kabbalat Shabbat ceremony at their pre-school. Thus, the parents not only raised awareness of an everyday experience of eating bread, they also made it relevant to a specific ritual that Jewish Israeli pre-school children usually anticipate and enjoy. Here, the parents provided a casual explanation that was not necessarily promoted by the features of the exhibit (neither bread nor Challah appeared in the exhibit). Table 4 presents examples of connections parents made to everyday life.

During the interactions, parents mediated their children's engagement with their surroundings by offering simple explanations and connecting back to previous experiences (e.g., Ellenbogen et al., 2004; Zimmerman \& McClain, 2016). The topic of food provided families various opportunities to use past experience from various settings such as home, the supermarket, television, and pre-school. For example, at the Tomatoes exhibit, one mother used the child's experience from the supermarket to explain how to use the exhibit and get information about tomatoes. Scholars have found that conversations about past experiences help young children organize and structure information in memory (Leichtman et al, 2017). Degotardi et al. (2019) found that children's learning deepens when their engagement involves opportunities to connect new information with existing knowledge. Pagano et al. (2020) noted that the procedure of "reminiscing" on shared past events is a way of engaging in reflection that is common within families following visits to informal settings such as museums. 


\section{Observation}

As evident from the examples in Table 4, parents used the exhibit as a resource and drew their children's attention to specific components of it to promote further engagement with the exhibit. We found that $75 \%$ of families directed their children's observation 80 times overall. Most instances consisted of very simple instructions directing the children to observe something, such as "Look at this," with or without a physical gesture (i.e., pointing).

\section{Example: Observation strategy: Family \#35, Mom \& Shahar (4.5 years old), Spirulina Exhibit}

Mom:

“Look at this green stuff (spirulina). Would you eat it?"

Shahar shakes her head no.

Mom:

"It says here that each tube has different amounts [of spirulina]. Let's take a look."

Mom and Shahar take a close look at the tubes, comparing the amount of algae in each one.

In this example, the family observed the exhibit itself to identify the phenomenon. In some cases, the phenomenon did not appear directly in the exhibit, and the children had to hypothesize and predict the phenomenon. For example, one father instructed his child,

"Look at the wheat seeds. What happens when we water them?”

In the exhibit, the seeds are laid out on a table, and above the table is a display of full-grown wheat plants (see Figure 2). Here, the parent used observation and prediction as a strategy for engaging his child to complete "the missing part", combining the resources the exhibit provided with previous knowledge resources.

Children observe the world around them every day, helping them to make sense of natural phenomenon, in a way that might sometimes be similar to scientific observations, however, children still require training to become 'scientific observers', a process that involves negotiating between disciplinary knowledge, theory, and practice (Eberbach \& Crowley, 2017). For example, Eberbach and Crowley (2017) have shown how parents helped children to make the transition from just seeing the natural world to scientifically observing nature, by pollinating plants during visit to botanical gardens. In our study, parents tried to mediate children's observation skills, usually by guiding them with questions.

\section{Asking Questions}

Studies examining family engagement at museums have found that when parents use elaborative questioning strategies, this generates positive outcomes for children's engagement and learning (Jant et al., 2014; VandermaasPeeler et al., 2016). Furthermore, Ash (2004) explored parental questions at dioramas, revealing that parents use a variety of strategies that invite children to co-construct meaning. We found that almost all the interactions in this study involved question-asking. Overall, in all the observed interactions, parents asked 216 questions. We counted 68 interactions, by $73 \%$ of the families, consisting of more than one question asked in a row (ping-pong). Research on parent-child engagement in a museum setting suggests that visiting museum exhibits accompanied a parent might influence children in various ways; for example, parents often foster children's exploration, draw analogies, and engage children in explanatory conversation that benefits their understanding of science-related concepts (Leichtman et al., 2017).

We found that parents asked their children different kinds of questions. Most were very short prompting questions, such as "What is this?" or "What do you see here?" or "How does this work?" Most often, parents asked a question and did not wait for an answer (rhetorical question); at times parents even asked and answered a question in the same breath.

When younger children were involved, parents tended to ask questions that entailed practicing counting ("How many do you see here?”) or identifying colors ("What color is this?”) or shapes ("What is this shape?"). Sometimes parents' questions also required practicing comparing shapes ("This is round and this is...?”) or giving examples of shapes or colors ("Is this tomato round?" "Are the coffee beans brown?"). However, on rare occasions and usually with older children (older than 6 years), parents asked more in-depth questions and waited for the children to respond, such as "Let's see, what does the research say about this?" or "Should we try? Can we make it bounce back?" or "Do you know the difference between wholewheat flour and white flour?"

The analysis shows that in the majority of families, overall, the parents were those who asked the questions. Only in a very few families did the children pose questions, and they were often very simplistic questions, such as "What is this?" or "What do we do here?" This in lines with others reporting on parents who ask WH-questions (e.g., where, why, when, who etc.) and associate the activities during the museum visit with children's past experiences and knowledge, which, in turn, demonstrate better understanding and memory of the visit than children whose parents do not engage with those practices (Benjamin et al., 2010; Haden et al., 2014).

However, in our study, parents used short, sometimes rhetorical questions (e.g., Taggart et al., 2020), mostly directing children's attention to the exhibit, but not necessarily co-constructing meaning. Scientific sense-making, which is considered by most as the primary learning process in informal settings (Ash, 2004; McClain \& Zimmerman, 2014; Zimmerman et al., 2010) was scarce in our study.

\section{Reading, Interpreting, and Naming}

We found that the instructional strategies of reading, interpreting, and naming were usually used in tandem (although not always). Overall, all families used those strategies (100\%), 342 times during our observations. Typically, when a family approached an exhibit one of the parents (usually the mother) read aloud the sign or instructions and interpreted them for the children, providing a technical or scientific explanation (see distribution in Table 3). After reading and interpreting the instructions in the sign, 
Table 5. Examples of parents' uses of the interpretation strategy

\begin{tabular}{|c|c|c|c|}
\hline $\begin{array}{c}\text { Family } \\
\# \\
\end{array}$ & Family members & Exhibit & Example \\
\hline 11 & $\begin{array}{l}\text { Mom, Grandma, } \\
\text { Grandpa, Maya (10), \& } \\
\text { Amit (4) }\end{array}$ & Snack Column & $\begin{array}{c}\text { Mom: We can see things made of cocoa. } \\
\text { Grandpa to Maya: Do you know where we can find cocoa beans? } \\
\text { Maya shakes her head no. } \\
\text { Grandpa: Cocoa trees grow in Mexico. }\end{array}$ \\
\hline 17 & Mom \& Tomer (8) & Spirulina Exhibit & $\begin{array}{l}\text { Mom: Today we have snacks that contain spirulina. Do you want me to buy it for you? } \\
\text { It's very healthy. It's got lots of protein. It's the food of the future, a super food. You will } \\
\text { eat it in the future. }\end{array}$ \\
\hline 18 & $\begin{array}{l}\text { Mom, Dad, Yonatan } \\
\text { (8), Yakir (4), \& an } \\
\text { infant }\end{array}$ & Tomatoes Exhibit & $\begin{array}{l}\text { Mom to Yonatan: You scan it like at the supermarket. } \\
\text { Yonatan scans the tomatoes. } \\
\text { Mom: Great! But you need to read what it says - they [the sign] tell you who the parents } \\
\text { are. This [tomato] is red. [It means] a short shelf-life. We need two parents, one with a } \\
\text { long shelf-life and one with a short shelf-life. If we have two [parents] with a short shelf- } \\
\text { life, it [the tomato] will go bad. }\end{array}$ \\
\hline
\end{tabular}

the parent(s) would name different objects in the exhibit (such as different kinds of legumes).

\section{Example: Family \#23, Mom \& Mor (11 years old), Tomatoes Exhibit}

Mom reads aloud the sign near the Tomatoes Exhibit, instructing Mor,

\section{"You need to scan the barcode."}

Mor scans the barcode, and Mom continues to read the sign out loud:

“... to prolong shelf-life, scientists use genetic engineering ... create mutations ... Do you know what mutations are?”

Mor:

$$
\text { "You tell me." }
$$

Mom:

"It's when you have a gene that develops in the wrong way."

In this example, the mother used the sign as a resource and read it aloud so that the child would hear what the sign said and gave her technical interpretations of what to do (scan the barcode). She then used a question (another form of the strategy) to explain the scientific content that appears on the sign (mutations). Table 5 presents additional examples of parents' uses of the interpretation strategy.

We also found that parents with children 7 years of age and older (second grade and up) tended to encourage their children to read the signs themselves and used the exhibits as a resource to facilitate practicing reading (performed 18 times by $23 \%$ of the families).

With some of the exhibits, naming played a big role in the family interactions. In the interactions at the Spirulina, Tomatoes, and Wheat exhibits, no further naming was observed after the initial naming: "This is spirulina." or "That is wheat." In contrast, at the Legumes Table and Snack Column exhibits, naming was at the center of all interactions.

\section{Example: Family \#2, Mom, Dad, \& Eden (6 years old), Legumes Table}

Dad:

"Look at all the seeds you see here!"

He takes Eden by the hand to the Legumes Table.

Mom:

“They are called legumes."

Dad:

“Chickpeas [points], lentils [points], beans [points], peanuts [points]. I do not know what those are. Flat beans [points], red lentils [points]. There are some here that I do not recognize."

The naming strategy represented in this example was observed frequently at the Legumes Table. Some parents named the legumes and pointed them out to their children; some asked the children to name what they recognized. Similar interactions were identified at the Snack Column, but often involved another strategy as well: parents would ask their children to name a particular ingredient and then state the kind of food containing that ingredient.

Example: Family \#7, Mom, Dad, \& Odel (5 years old), Snack Column

The family approaches the Snack Column exhibit.

Dad:

"Odel, do you know what they are telling you here [referring to the sign]? That all those things are made with tahini."

Mom:

"It says that the main ingredient in tahini is sesame seeds. Do you know what else is made from sesame seeds?”

Odel does not respond.

Mom:

"Halva." 
Mom:

“Odel, let's check what the main ingredient in cereal is. That's something you really like..."

Odel:

“Chocolate?"

Mom laughs:

“No, it's yellow. What yellow things do you like to eat?"

Odel:

“Corn!”

Mom:

"That's right! Cereal is made from corn. You know what else is made from corn?"

Odel does not respond.

Mom:

"Bamba [an Israeli snack product].”

Dad:

"Bamba is made from peanuts."

Mom and Dad debate for a moment about what Bamba is made from and then go and check the ingredients list [on the back of the snack packet].

Mom:

"Bamba is made from peanuts and corn."

This example also includes the use of question-asking and connection to everyday life.

The four described strategies emerged as dominant in the observations we analyzed, but some families clearly used other strategies as well. A few parents used songs to engage their children with the exhibit or played games (for example, a game of finding as many snacks containing peanuts). At two specific exhibits-the Spirulina Exhibit and the Roots Exhibit (a nonfood related exhibit)-some parents used the feeling of disgust to prompt their children's engagement with the exhibit. Here, the parents understood the intention of the exhibit designers (to trigger a feeling of disgust) and used it in the interaction with the children, who as expected, mostly reacted verbally with "Yuck!"

Overall, parents were found to engage in sense-making with their children, while providing scientific interpretations of the exhibits (48\% of families explained the scientific content, overall, 37 times), this is supported by other research that found similar interactions (Crowley et al., 2001; Fender \& Crowley, 2007; Jant et al., 2014; Riedinger \& Taylor, 2019; Zimmerman et al., 2010). However, even when the scientific explanation was provided during our observations, it was usually short and superficial, and sometimes incorrect scientific explanations. It would be interesting to explore if those spontaneous explanations effect children's understanding, as was reported by Fender and Crowley (2007). In addition, the sense-making was usually not directly aligned with the scientific content of the exhibits. For example, in the Snack Column exhibit, the goal was to introduce the ingredients in snacks, mainly plant products (e.g., wheat and corn) and highlight the relationship between those and other food groups (e.g., carbohydrates). Interestingly, although the parents focused on more familiar concepts, using strategies such as naming and asking questions, the selected previous experience was that of eating cornflakes as a favorite meal, rather than of the intended scientific content of the exhibit (i.e., to emphasize the relationship between food groups). One might ask if there is a benefit to non-scientific participation while exploring scientific phenomena. Such non-scientific participation of family engagement in artifact exploration was also found by Zimmerman and McClain (2014a, 2014b) and Zimmerman et al. (2013), who investigated family social interactions on a nature trail. In their research, families were given various artifacts such as, magnifying glasses, bug boxes, and binoculars to use (if they wish to) during a hike. Their findings suggest that nearly half the times families used the magnifying glass for non-scientific, or leisure use, they also found that the conversations around the exploration were unrelated to science topics.

This phenomenon was similarly prominent at the Wheat exhibit: As implied by the name of the exhibition-Fields of Tomorrow-the exhibits' intended focus is agriculture and human engineering of plants to meet the food needs of Earth's growing human population. Yet only one parent in our sample referred to that scientific content:

\section{Example: Family \#37, Mom, Dad, \& three sons (7, 5, \& 2 years old), Wheat Exhibit}

Dad explains to the older boys:

\begin{abstract}
"We have here two types of wheat - one with a short stalk and one with a longer one. The longer one bends in the wind, and this makes it difficult to harvest. So, scientists engineered the plant to make the stalk shorter so it will be easier to harvest."
\end{abstract}

This example was unique in that it contained both a scientific explanation and correlated with the exhibit's goal. All other parents only talked about the fact that we make bread from wheat.

A few of the parents noticed some of this misalignment during their visit. For example, one mother (Family \#16) stated,

“They [the museum] could have provided the parents with more explanations. I don't know everything, so I can't explain it to the kids.”

\section{CONCLUSIONS}

The aim of this study was to examine how parents use exhibits' features during a family visit around exhibits at a science museum. First, we found that the food-related exhibits attracted more visitors than other exhibits. Second, parents use the physical environment (mainly signs) as a resource to 
engage their children with science, taking on the role of "experts" and instructing the novice children (e.g., Ash, 2004; Crowley et al., 2001). Parents used four main instructional strategies while interacting with the exhibits. Reading the signs and providing technical explanations regarding the operation of the exhibits were the most prevalent strategies. This study supports the notion that parent-child interactions and parents' instructions serve as an important facilitator in shaping children's learning experiences (Ash, 2003, 2004; Zimmerman et al., 2010).

In our study, parents mainly used one of the exhibit's features, the signs, in their instructions. Apparently, parents adhere to what they know, employing the same instructional strategies that they use in other settings (e.g., at home), using the museum signage as a resource to repeat a familiar parentchild engagement, such as reading and asking questions. However, in this research, parents used short, sometimes rhetorical questions (e.g., Taggart et al., 2020), mostly directing children's attention to the exhibit, but not necessarily co-constructing meaning. Parents read the signs aloud to their children (e.g., Diamond, 1986), most often with no elaboration on the parents' part. This raises a question regarding the purpose of the signage at museum exhibits if visitors do not seem to know how to effectively use the resource. Furthermore, parents use simple questions and noticing strategies, as they are accustomed to these strategies. The museum offered no instructions on how to mediate the exploration or the content, perhaps presuming that parents should be familiar with mediation strategies without any explicit guidance on the museum's part.

In our study, parents often provided more technical explanations regarding the operation of the exhibits to their children, and only sometimes interpreted the scientific content, engaging in scientific sense-making. As previously mentioned, Szechter and Carey (2009) found that in a science museum parents tended to engage in "learning talk" more than children. Similarly, in this study we found that parents mainly provide explanations and connect to past experiences, but do not describe evidence or make predictions (Szechter \& Carey, 2009). In order to achieve more profound engagement, as others have demonstrated, museums should adopt a variety of strategies to equip parents with more suitable mediational means.

Our study has shown that when an exhibit has features that can capture the attention and raise curiosity of visitors, it has the potential to be attractive and stimulating for both children and adults. The importance of this study lies in the considerable potential possessed by food related exhibits in capturing visitors' attention. Although museum staff strive to design interactive exhibits to do so, our study has revealed that even non-interactive exhibits (such as the Legume Table and the Snack Column) attract visitors, presumably due to their connection to the visitors' lives. However, this study points out a misalignment between the exhibition goals and the expected engagement of the visitors. Although very attractive, the exhibits in our study were unsuccessful in their attempt to engage families around the intended socio-political content of the exhibition (global and regional sustainability in agriculture). Exhibit design plays a significant role in drawing visitors' attention (Shaby et al., 2017), but museum staff needs to keep the exhibition goal in mind, as we discuss in the next section.

\section{Implications}

While designing exhibits or creating educational activities in informal science environment, educators should consider and support the role of parents (and caregivers) in the learning process (NRC, 2009). Given that museum settings provide families with rich science learning opportunities, we argue that more attention should be paid towards how families use resources to engage in scientific sense-making. From the museum's perspective, the scientific engagement should be related to the goals of the exhibits, as the museum educators and exhibit designers view them (Shaby et al., 2016).

Our study revealed numerous such missed opportunities, most prominently at the Snack Column exhibit. The sociopolitical goal of that exhibit is to demonstrate that most of the ingredients in snacks are plant-based (sesame seeds, peanuts, corn, etc.), with emphasis on the food groups each ingredient belongs to (protein, carbohydrates, fats, etc.) in order to highlight the need for more sustainable agricultural solutions for growing plants. However, parents tended to prompt engagement regarding only one type of ingredient comprising a snack (e.g., peanuts) and comparing it with other foods that have that same ingredient (e.g., Bamba and peanut butter). Museum staff must provide more explicit mediational means, such as signs, to promote scientific sense-making that is aligned with the exhibit's goal.

Informal environments should prompt and support visitors while interpreting their learning experiences considering relevant prior knowledge, experiences, and their interests. Though the design of some of the exhibits in our study may take this into account, based on the interactions we observed, it seems that the connection to the visitors' lives were unclear and somehow abstract. For example, at the Spirulina exhibit, which is meant to demonstrate superfoods, a child we observed did not respond to his parent's explanations, despite the parent's attempt to conceptualize the message for the child ("You will eat it in the future"). The parent did not mention "why" the child would eat this in the future, even though the threat of food security for the growing population on earth is one of the exhibition's goals. One strategy that could be used by the museum is to run a pilot of the exhibits to observe visitors' interactions and draw from how the visitors relate to the exhibits. For example, we observed that for many parents the Wheat exhibit evoked recollections about Challah bread, or they sang familiar songs about wheat. The museum could use those examples as prompts on the exhibit signs, to engage visitors in a way that relates better to their lives. In a pilot study, families could be interviewed as well about their experiences in the exhibitions hall and could be reminded of specific interactions they had (such as singing a song) to explore further their views of various exhibits and best ways to interact with it, in their opinion.

Our main recommendation is to provide parents with more explicit mediational means that connect closely to the exhibit/exhibition goal. One mother commented on this issue to one of the researchers saying: 
"They [the museum] could have explained it [the exhibit] better to the parents. I do not know what to do here and I do not know what I need to explain to my child."

The need for better mediational means in informal environments (not only science museums) is the outcome of many studies. McClain and Zimmerman (2019) suggested that a more structured learning environment can support opportunities for conversations between family members to promote connections between the scientific phenomena in the learning environment and the family past shared experiences. Furthermore, Harris and Winterbottom (2018) showed how family learning can be developed during a facilitated workshop to spark scientific talk between family members and encourage an inquiry-based approach. Povis and Crowley (2015) found that activities as simple as exploring dioramas with torches can increase the levels of parent-child joint attention around an object, that leads to increased engagement in learning talk about that object. Furthermore, Gutwill and Allen (2010) as well as Allen and Gutwill (2009) developed inquiry games for family that improved certain inquiry practices, compared to control group (that did not experience that specific design element). Similarly, the Skyscraper Challenge area of the Chicago Children's Museum's Skyline exhibit was designed to enhance family interactions in a STEM-related exhibit. This research observed families from diverse backgrounds addressing the fact that parents can also vary in their instructional behaviors with their children, including the concepts they talk about, the level of their instruction, and the amount and valence of feedback provided to their children (Haden et al, 2014). Since the main resource used by parents is the museum signage, Gutwill and Dancstep (2017) suggest, for example, using flip-labels to encourage question-asking that can promote visitors metacognitive talk while engaging with those exhibits.

Another way of looking at this misalignment between the exhibit goal and visitor engagement is to make the exhibit goals more relevant to the non-expert audiences' prior knowledge, motivation, and needs, in addition to labelling texts that are related directly to the exhibit artifacts and elements. Furthermore, museums can design exhibitions that have clear and meaningful big ideas; capture affordances and best practices; and use prototyping during the design process to adjust the interpretive strategies.

\section{Limitations and Future Research}

In this research we did not interview the museum staff and relied on the signage to inform us about the goals of the exhibits, future studies should take the museum educators views on the interaction as well. This study used observations and our findings derived from behavioral analysis of the visitors. Further, we only took field-notes and did not video record the engagement. Therefore, we can only claim that the visitor talk did not consist of scientific sense-making, but we lack further exploration regarding thoughts about science that could be revealed in interviews. Furthermore, in this research we focused our analysis on the parents. Additional analysis on the children's responses, addressing the following for example:
1. Did the children direct their attention as their parents suggested?

2. How long did the children observe the exhibit?

3. Do older children have more patience and interest in observing the exhibit?

This can inform museum educators on more efficient responses in expanding children's attention. Another limitation of only taking field-notes is the lack of access to insights from body engagement in the interactions. To capture a fuller picture of the experience, we recommend that a future research include video recordings and interviews with visitors. In this study we collected data on Saturdays, a day in which some groups of the population will not engage in such recreational activities (such as Shabbat observer Jews). Therefore, we suggest exploring additional visitor groups from diverse cultural sectors of the population to examine how various communities of practice respond to socio-political goals of the exhibits and whether they utilize the exhibits' features in culturally different manners.

Author contributions: All co-authors have involved in all stages of this study while preparing the final version. They all agree with the results and conclusions.

Funding: No external funding is received for this article.

Declaration of interest: The authors declare that they have no competing interests.

Ethics approval and consent to participate: Not applicable.

Availability of data and materials: All data generated or analyzed during this study are available for sharing when appropriate request is directed to corresponding author.

\section{REFERENCES}

Allen, S., \& Gutwill, J. P. (2009). Creating a program to deepen family inquiry at interactive science exhibits. Curator: The Museum Journal, 52(3), 289-306. https://doi.org/10.1111/j. 2151-6952.2009.tb00352.x

Andre, L., Durksen, T., \& Volman, M. L. (2017). Museums as avenues of learning for children: A decade of research. Learning Environments Research, 20(1), 47-76. https://doi.org/10.1007/s10984-016-9222-9

Ash, D. (2003). Dialogic inquiry in life science conversations of family groups in a museum. Journal of Research in Science Teaching, 40(2), 138-162.https://doi.org/10.1002/tea.10069

Ash, D. (2004). Reflective scientific sense-making dialogue in two languages: The science in the dialogue and the dialogue in the science. Science Education, 88(6), 855-884. https://doi.org/10.1002/sce.20002

Benjamin, N., Haden, C. A., \& Wilkerson, E. (2010). Enhancing building, conversation, and learning through caregiverchild interactions in a children's museum. Developmental Psychology, 46(2), 502. https://doi.org/10.1037/a0017822

Bricker, L. A., \& Bell, P. (2014). "What comes to mind when you think of science? The perfumery!": Documenting science-related cultural learning pathways across contexts and timescales. Journal of Research in Science Teaching, 51(3), 260-285. https://doi.org/10.1002/tea.21134 
Callanan, M. A., \& Jipson, J. L. (2001). Children's developing scientific literacy. In Crowley, K., Schunn, C. D., \& Okada, T. (Eds.), Designing for science: Implications from everyday, classroom, and professional settings (pp. 19-43). Routledge.

Callanan, M. A., Legare, C. H., Sobel, D. M., Jaeger, G. J., Letourneau, S., McHugh, S. R., Willard, A., Brinkman, A., Finiasz, Z., Rubio, E., Barnett, A., Gose, R., Martin, J. L., Meisner, R., \& Watson, J. (2020). Exploration, explanation, and parent-child interaction in museums. Monographs of the Society for Research in Child Development, 85(1), 7-137. https://doi.org/10.1111/mono.12412

Callanan, M. A., Siegel, D. R., \& Luce, M. R. (2007). Conventionality in family conversations about everyday objects. New Directions for Child and Adolescent Development, 115, 83-97. https://doi.org/10.1002/cd.184

Corbin, J. S., \& Strauss, A. A. 2008. Basics of qualitative research: Techniques and procedures for developing grounded theory. SAGE. https://doi.org/10.4135/9781452230153

Crowley, K., \& Jacobs, M. (2002). Building islands of expertise in everyday family activity. In G. Leinhardt, K. Crowley, \& $\mathrm{K}$. Knutson (Eds.), Learning conversations in museums (pp. 333-356). Lawrence Erlbaum Associates.

Crowley, K., Callanan, M. A., Jipson, J. L., Galco, J., Topping, K., \& Shrager, J. (2001). Shared scientific thinking in everyday parent-child activity. Science Education, 85(6), 712-732. https://doi.org/10.1002/sce.1035

Degotardi, S., Johnston, K., Little, H., Colliver, Y., \& Hadley, F. (2019). “This is a learning opportunity": How parent-child interactions and exhibit design foster the museum learning of prior-to-school aged children. Visitor Studies, 22(2), 171191. https://doi.org/10.1080/10645578.2019.1664849

Diamond, J. (1986). The behavior of family groups in science museums. Curator: The Museum Journal, 29(2), 139-154. https://doi.org/10.1111/j.2151-6952.1986.tb01434.x

Eberbach, C., \& Crowley, K. (2017). From seeing to observing: How parents and children learn to see science in a botanical garden. Journal of the Learning Sciences, 26(4), 608-642. https://doi.org/10.1080/10508406.2017.1308867

Ellenbogen, K. M., Luke, J. J., \& Dierking, L. D. (2004). Family learning research in museums: An emerging disciplinary matrix? Science Education, 88(S1), S48-S58. https://doi.org/10.1002/sce.20015

Fender, J. G., \& Crowley, K. (2007). How parent explanation changes what children learn from everyday scientific thinking. Journal of Applied Developmental Psychology, 28, 189-210. https://doi.org/10.1016/j.appdev.2007.02.007

Gutwill, J. P., \& Allen, S. (2010). Facilitating family group inquiry at science museum exhibits. Science Education, 94(4), 710-742. https://doi.org/10.1002/sce.20387

Gutwill, J. P., \& Dancstep, T. (2017). Boosting metacognition in science museums: Simple exhibit label designs to enhance learning. Visitor Studies, 20(1), 72-88. https://doi.org/10.1080/10645578.2017.1297132
Haden, C. A., Jant, E. A., Hoffman, P. C., Marcus, M., Geddes, J. R., \& Gaskins, S. (2014). Supporting family conversations and children's STEM learning in a children's museum. Early Childhood Research Quarterly, 29(3), 333-344. https://doi.org/10.1016/j.ecresq.2014.04.004

Harris, E., \& Winterbottom, M. (2018). 'Why do parrots talk?'co-investigation as a model for promoting family learning through conversation in a natural history gallery. Journal of Biological Education, 52(1), 89-100. https://doi.org/10.1080/00219266.2017.1408934

Jant, E. A., Haden, C. A., Uttal, D. H., \& Babcock, E. (2014). Conversation and object manipulation influence children's learning in a museum. Child Development, 85(5), 20292045. https://doi.org/10.1111/cdev.12252

Leichtman, M. D., Camilleri, K. A., Pillemer, D. B., AmatoWierda, C. C., Hogan, J. E., \& Dongo, M. D. (2017). Talking after school: Parents' conversational styles and children's memory for a science lesson. Journal of Experimental Child Psychology, 156, 1-15. https://doi.org/10.1016/j.jecp.2016. 11.002

Lincoln, Y. G., \& Guba, E. G. (1985). Naturalistic inquiry. SAGE. https://doi.org/10.1016/0147-1767(85)90062-8

McClain, L. R., \& Zimmerman, H. T. (2014). Prior experiences shaping family science conversations at a nature center. Science Education, 98(6), 1009-1032. https://doi.org/10. 1002/sce. 21134

McClain, L. R., \& Zimmerman, H. T. (2019). Family connections to local science issues: how scientists use questions to engage families in personally-relevant learning during science-themed workshops. International Journal of Science Education, Part B, 9(2), 154-170. https://doi.org/10.1080/21548455.2019.1584419

National Research Council. (2000). From neurons to neighborhoods: The science of early child development. National Academy Press.

National Research Council. (2009). Learning science in informal environments: People, places, and pursuits. National Academies Press.

Pagano, L. C., Haden, C. A., \& Uttal, D. H. (2020). Museum program design supports parent-child engineering talk during tinkering and reminiscing. Journal of Experimental Child Psychology, 200, 104944. https://doi.org/10.1016/j. jecp.2020.104944

Pattison, S. A., Ewing, S., \& Frey, A. K. (2012). Testing the impact of a computer guide on visitor learning behaviors at an interactive exhibit. Visitor Studies, 15(2), 171-185. https://doi.org/10.1080/10645578.2012.715010

Povis, K. T., \& Crowley, K. (2015). Family learning in objectbased museums: The role of joint attention. Visitor Studies, 18(2), 168-182. https://doi.org/10.1080/10645578.2015. 1079095

Riedinger, K., \& Taylor, A. (2019). Leveraging parent chaperones to support youths' learning during an out-ofschool field trip to a marine science field station. In Fauville, G., Payne, D. L., Marrero, M. E., Lantz-Andersson, A., \& Crouch, F. (Eds.), Exemplary practices in marine science education A resource for practitioners and researchers 
(pp. 59-80). Springer. https://doi.org/10.1007/978-3-31990778-9_4

Shaby, N., Ben Zvi Assaraf, O., \& Tal, T. (2017). The particular aspects of science museum exhibits that encourage students' engagement. Journal of Science Education and Technology, 26(3), 253-268.

Shaby, N., Ben Zvi Assaraf, O., \& Tishler, C. E. (2016). The goals of science museums in the eyes of museum pedagogical staff. Learning Environments Research, 19(3), 359-382.

Szechter, L. E., \& Carey, E. J. (2009). Gravitating toward science: Parent-child interactions at a gravitational-wave observatory. Science Education, 93(5), 846-858. https://doi.org/10.1002/sce.20333

Taggart, J., Ellwood, M., Vasc, D., Chin, S., \& Lillard, A. S. (2020). Parents' roles and question-asking during pretend and real activities. Review of Social Development. https://doi.org/10.1111/sode.12436

Vandermaas-Peeler, M., Massey, K., \& Kendall, A. (2016). Parent guidance of young children's scientific and mathematical reasoning in a science museum. Early Childhood Education Journal, 44(3), 217-224. https://doi.org/10.1007/s10643-015-0714-5

Vedder-Weiss, D. (2017). Serendipitous science engagement: A family self-ethnography. Journal of Research in Science Teaching, 54(3), 350-378.https://doi.org/10.1002/tea.21369
Willard, A. K., Busch, J. T., Cullum, K. A., Letourneau, S. M., Sobel, D. M., Callanan, M., \& Legare, C. H. (2019). Explain this, explore that: A study of parent-child interaction in a children's museum. Child Development, 90(5), 598-617. https://doi.org/10.1111/cdev.13232

Zimmerman, H. T., \& McClain, L. R. (2014a). Exploring the outdoors together: Assessing family learning in environmental education. Studies in Educational Evaluation, 41, 38-47. https://doi.org/10.1016/j.stueduc. 2013.09.007

Zimmerman, H. T., \& McClain, L. R. (2014b). Intergenerational learning at a nature center: Families using prior experiences and participation frameworks to understand raptors. Environmental Education Research, 20(2), 177-201. https://doi.org/10.1080/13504622.2013.775219

Zimmerman, H. T., \& McClain, L. R. (2016). Family learning outdoors: Guided participation on a nature walk. Journal of Research in Science Teaching, 53(6), 919-942. https://doi.org/10.1002/tea.21254

Zimmerman, H. T., McClain, L. R., \& Crowl, M. (2013). Understanding how families use magnifiers during nature center walks. Research in Science Education, 43(5), 19171938. https://doi.org/10.1007/s11165-012-9334-X

Zimmerman, H. T., Reeve, S., \& Bell, P. (2010). Family sensemaking practices in science center conversations. Science Education, 94(3), 478-505. https://doi.org/10.1002/sce. 20374

Zimmerman, H., Perin, S., \& Bell, P. (2010). Parents, science, and interest. Museums \& Social Issues, 5(1), 67-86. https://doi.org/10.1179/msi.2010.5.1.67 